УДК 663.916.1

DOI: $10.17277 /$ vestnik.2015.03.pp.475-487

\title{
RHEOLOGICAL PROPERTIES OF CANDY MASS: RESULTS AND PRACTICAL APPLICATIONS
}

\author{
E. I. Muratova, P. M. Smolikhina
}

\section{Department "Technology and Equipment of Food and Chemical Industries", TSTU; topt@topt.tstu.ru}

Keywords: adhesion; candy mass; powders of plant materials; rheology; technological regimes.

Abstract: The article analyzes domestic and foreign information resources devoted to the study of the rheological behavior of confectionery masses and justifies the necessity to conduct a comprehensive study of the rheological properties of raw materials, semi-finished and finished products to support optimal modes of production and to produce products with the specified structural-mechanical characteristics.

The research results of the rheological behavior of jelly, fondant and whipped candy mass of different classic recipes and recipes with the introduction of powders and hydro-alcoholic extracts from plant raw materials.

The research results can be used for recommendations for selecting modes of thermal mechanical processing of fondant and jelly masses at the stage of tempering and molding. It was found that the nature of changes in plastic strength of semi-finished products depends on modes of structure formation and influence of additives of plant origin on this process. The paper also studies the effect of phytonutrients and vegetable powders on the strength of adhesive contacts between the layers of candy mass in forming multilayered confectionery products.

Taking into consideration peculiarities of physical-chemical interactions between additives of plant origin with other recipe ingredients of candy mass, an explanation of the mechanisms of their influence on the rheological properties of semi-finished products as well as structural and mechanical characteristics of the finished products has been presented in the paper.

\section{Introduction}

Rheological, structural and mechanical characteristics are the most important indicators of candy mass properties where candy mass is a semi-finished product entering further process steps. These characteristics also determine structural and mechanical properties of the finished product. The study of adhesion properties allows evaluating the possibility of using various molding methods or combination of candy mass with different physical-chemical and rheological properties for making combined confectionery.

In recent years domestic and foreign journals have published a number of studies on the rheological behavior of confectionery mass and structure of finished products. In [1] rheological properties of syrups with different sweeteners (sorbitol, maltodextrin, aspartame, etc.) are shown. For example, in $[2,3]$ the authors give recommendations for 
building and choosing rheological models which reflect main differences in flow types observed in fondant and whipped candy mass. In $[4,5]$ we can see the results of modeling and optimization of rheological properties of jelly mass using different types of gelling agents. The authors of [6] evaluated the effect of temperature, xanthan gum and fructose on the rheological behavior of blueberry puree and built statistical models that can be used to develop recipes with specified viscosity for various concentrations of additives. The research results of the adhesive properties of confectionery semi-finished and finished products and practical advice on the choice of molding methods are given in $[7,8]$.

Constantly expanding the range of products as well as using non-conventional raw materials in candy recipes actualizes the problem of studying the rheological behavior of candy mass and bank data on the influence of recipe ingredients and process conditions on technological properties of semi-finished products and stability of structural and mechanical properties of finished products during the storage period.

In this regard, there is a need for a thorough study of the rheology of candy mass with the addition of non-traditional raw materials and structural and mechanical characteristics of candies derived from them. The aim of the research is to validate the modes of candy production using enrichers in the form of powders from local vegetable raw materials on the basis of studying rheological, structural and mechanical properties of semi-finished products.

\section{The research results of rheological properties of candy mass and structural-mechanical characteristics of candy bodies}

The objects of the study were samples of fondant, jelly and whipped mass and candies made on their basis according to classic recipes, as well as with the addition of vegetable powders (pumpkin, carrot) and medicinal-technical raw materials (nettle leaves, lemon balm, raspberry) of various concentration and dispersion. Herbal additives used in the form of powder, hydrated powders (puree) and water-alcoholic extracts.

The study of rheological properties of semi-finished products and structuremechanical characteristics of candy bodies were performed on viscotester HAAKE VT6R plus (Thermo Fisher Scientific, Germany) and texture analyzer Brookfield CT-3 (Brookfield Engineering laboratories, inc., USA) equipped with a wide range of sensors, devices and accessories to meet the challenges associated with the analysis and measurement of texture. Detailed description of methods for analysis of raw materials, semi-finished and finished products is given in [8].

Studying rheological properties of investigated candy mass has shown that, irrespective of the recipe, they belong to pseudoplastic materials. In a wide range of shear rates $0-100 \mathrm{~s}-1$ the flow of the fondant mass is well approximated by the equation of Herschel-Bulkley, while the jelly and whipped mass satisfies the equation of Ostwald de Waele. In all cases, the rheological curves are well approximated by a linear function over a fairly wide range of shear rates (by a factor of no less than 0.98 approximation), which explains the choice and use of these rheological equations.

The curves of changes in viscosity versus shear rate have a form that is characteristic of structured systems. The viscosity decreases when the shear rate is increasing and especially fast in the range of relatively low shear rates, while the further increase in rate varies viscosity slightly. This rheological property is explained by the fact that in a stationary environment the arrangement of the particles is characterized by strong randomness, and under the influence of increasing shear forces the orientation of the particles in the flow direction is raising. Increasing the rate leads to decreasing the interaction between particles. Tests were conducted at temperatures typical of molding for this candy mass (Fig. 1). 


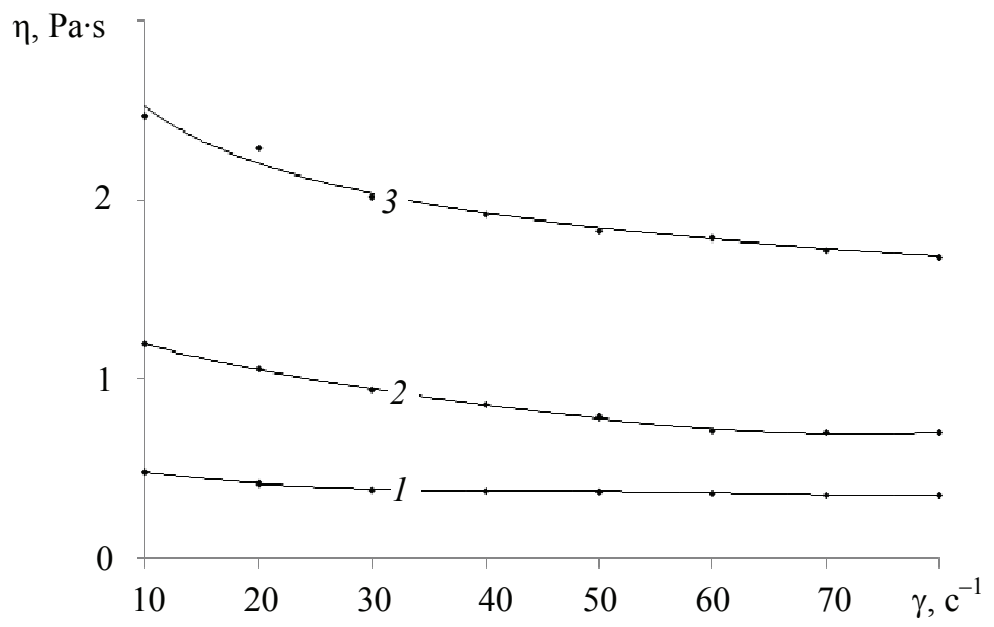

Fig. 1. Dependence of the candy mass viscosity on shear rate: 1 - jelly mass $\left(85^{\circ} \mathrm{C}\right) ; 2$ - fondant mass $\left(70^{\circ} \mathrm{C}\right) ; 3$ - whipped mass $\left(50^{\circ} \mathrm{C}\right)$

The viscosity of the whipped mass is five times higher than jelly mass and twice than fondant mass that is due to the presence in the system of a surfactant adsorbed and coagulated to egg protein films forming strong bonds and large amounts of air phase.

Thus, adding dry powder from 2 to $10 \%$ (dispersity of $0.14 \ldots 0.25 \mathrm{~mm}$ ) into the whipped mass increases the viscosity in $3 \ldots 10$ times, hydrated - in $3.5 \ldots 11.0$ times. The used additives have high adsorption and water-holding capacity, therefore when mixed with the candy mass they swell and form a spatial grid with strong intermolecular bonds. This leads to the "expansion" of the system which causes the reduction in thickness of dispersion environment layers and increase of resistance force, and, accordingly, significant increase in viscosity (Fig. 2).

A stronger effect of the hydrated powders, besides the phenomena described above, may be connected with the restoration of powder polymeric structures during its hydration and the dissociation of organic amino acid capable of participating in the jelly forming process which leads to hardening of the mass structure and a high viscosity, respectively.

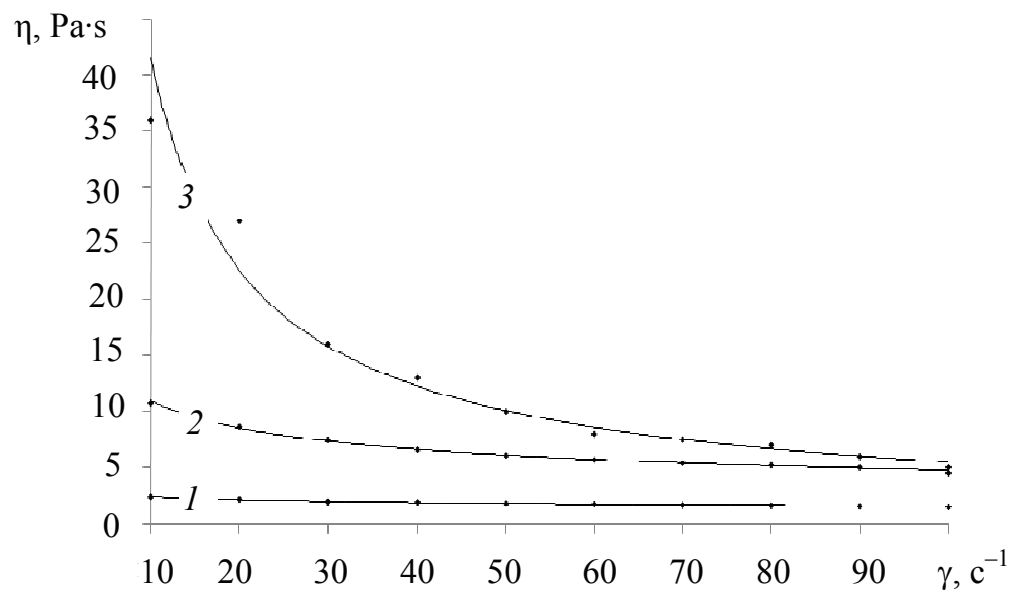

Fig. 2. Dependence of the whipped mass viscosity on deformation rate:

1 - control; 2,3 - with the addition of $5 \%$ dry and $5 \%$ hydrated vegetable powder respectively 
Adding powdered vegetable semi-finished products of different dispersion into the candy mass significantly changes the rheology of semi-finished products. Decreasing the size of nettle powder particles results in increasing the viscosity of candy mass (Fig. 3).

Plastic strength of candy bodies is a key indicator for characterizing the form retention quality. Changes in strength can show the process of structure formation the rate of which is of great importance for selecting regimes for structure formation process of candy mass $[8,9]$. The analysis of experimental studies about the effect of functional ingredients on the process of jelly mass formation showed that the use of powder reduces the plastic strength of jelly by $22 \%$ (Fig. 4).

Introduction of vegetable powders at the tempering stage of the jelly mass leads to destruction of the jelly monolithic and formation of uneven structure. Polysaccharides of powders that have high sorption properties violate hydrostatic equilibrium while absorbing moisture from the system the result of which becomes an irregular jelly body.

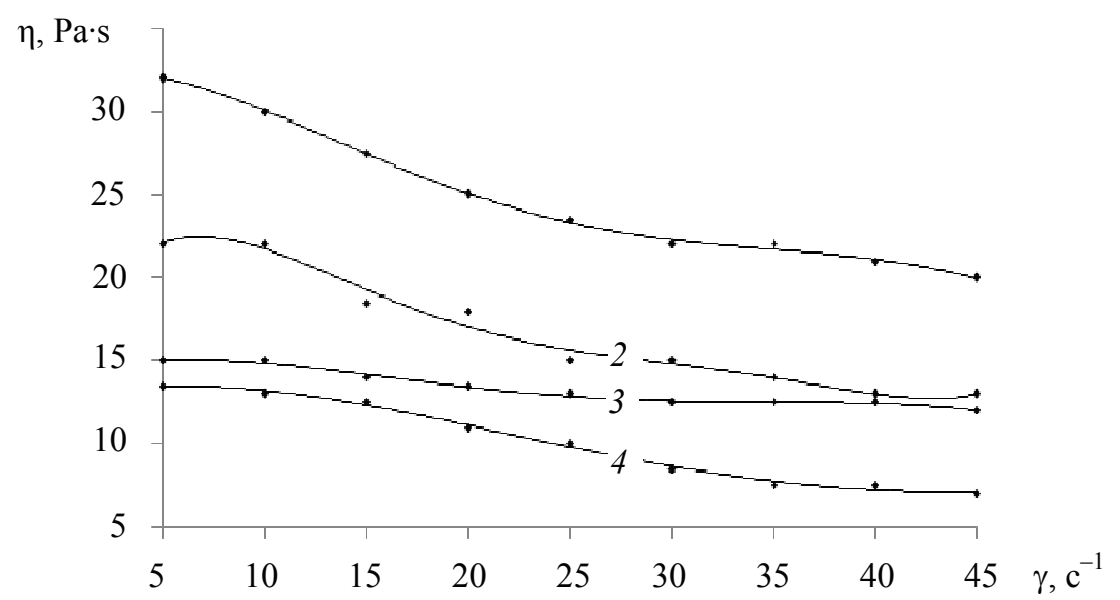

Fig. 3. Dependence of the fondant mass viscosity on the shear rate for different dispersion of the nettle powder, $\mathbf{m m}$ :

$1-0.08 \ldots 0.14 ; 2-0.14 \ldots 0.20 ; 3-0.20 \ldots 0.25 ; 4-0.25 \ldots 0.50$

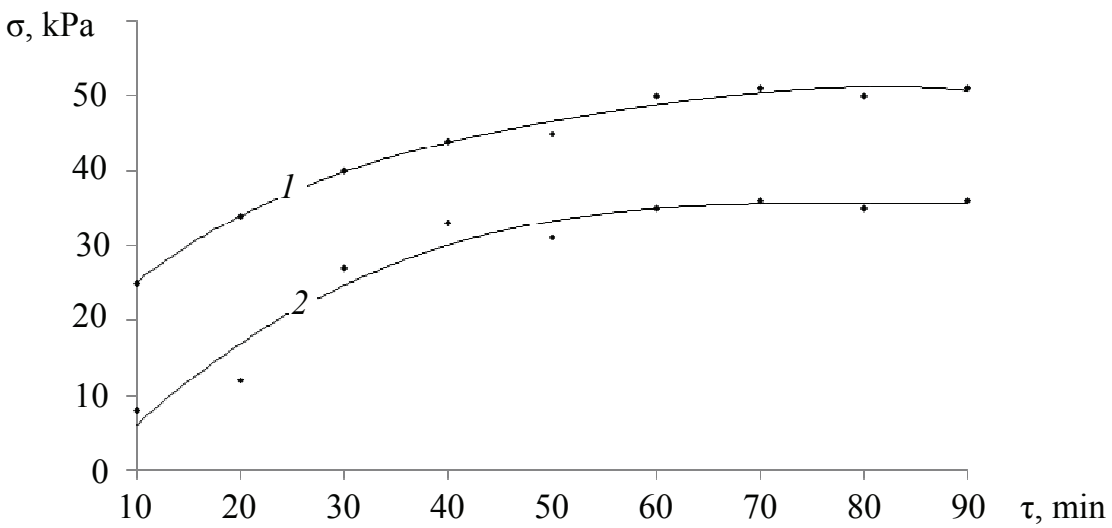

Fig. 4. Changes in the jelly plastic strength during structure formation process: 1 - control; 2 - with the addition of $0.5 \%$ pumpkin powder 
Introduction of vegetable powders at the tempering stage of the jelly mass leads to destruction of the jelly monolithic and formation of uneven structure. Polysaccharides of powders that have high sorption properties violate hydrostatic equilibrium while absorbing moisture from the system the result of which becomes an irregular jelly body.

When introducing the functional additives with pectin at the syrup preparation stage we can see the maximum dissolving and swelling of the polysaccharide powder. The formed jelly surface is smooth; on the fracture it is glassy with even distribution of insoluble fiber parts (Fig. 5).

The strength of whipped jellies with the use of powdered semi-finished products, on the contrary, increases due to the combined action of agar molecules and pectin substances presented in vegetable powders in large quantities. Thus, the hydrated powder increases the strength 2.0 fold, the dry powder -8.0 fold. When using hydrated powder the whipped mass strength increases owing to additional filling of the space frame surrounding the bubbles with swollen fibers of the vegetable powder. Gelation occurs within 40 minutes after casting at a temperature of $20 \ldots 22^{\circ} \mathrm{C}$, but a large amount of swollen polysaccharides makes the mass aqueous and prone to syneresis.

In samples containing dry powder syneresis is avoided by narrowing the channel, increasing the roughness of the walls and forming local ,gates" from the particles not adhered to the bubbles [10]. However, the presence of solid particles may have the opposite effect: they may undergo the adsorption of surfactants and the concentration decrease of surfactants in the solution leads to the increase of the surface tension and decrease of the foam dispersion, whereby the syneresis speed can be boosted.

Factors affecting the rate of fondant mass structuring are the ratio of solid and liquid phases, the presence of large crystals, the concentration and dispersion of functional additives, and body temperizing modes. The rate of fondant mass structuring can be judged by the increase in the limit shear stress [11].

For classical fondant mass at low temperatures $\left(70 \ldots 75^{\circ} \mathrm{C}\right)$ the limiting shear stress raises dramatically in a short period of time which indicates a high rate of sucrose crystallization. A high degree of supersaturation of the solution leads to intensive crystallization of sucrose not only on the surface but also in internal layers of the body. Structuring process in the mass casting with temperature of $95^{\circ} \mathrm{C}$ is slower and the mass cast at temperature of $100{ }^{\circ} \mathrm{C}$ reaches normal consistency (critical shear stress of $30 \ldots 40 \cdot 103 \mathrm{~N} \cdot \mathrm{m}^{-2}$ ) after 3 hours of structure formation process [12].

The structure formation process of the fondant mass can be traced according to increase in the strength of the structure of candy body. Figure 6 shows the dependence of the strength of the fonadant sample on the depth of the indenter.

On the surface of the semi-finished product there is a dense crystalline crust formation the hardness of which increases during the first hour (up to $1600 \mathrm{~g}$ ), and after two hours of temporizing the thickness reaches $2.5 \mathrm{~mm}$. Inside the formed body there is thick mass with large crystals of sucrose (the presence of crystals characterizes the presence of peaks within curve) (section $3^{*}$ ). In the crystallization process the adhesion of samples decreases to stainless steel.

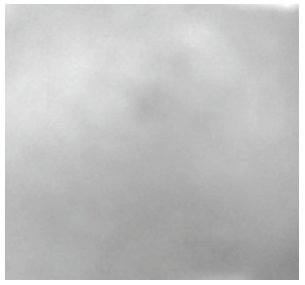

a)

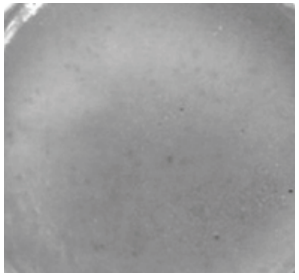

b)

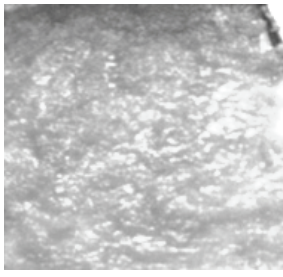

c)

Fig. 5. Jelly mass with the addition of vegetable powders $3 \%$ :

$a$-control; $b$ - at the stage of syrup production; $c$ - at the tempering stage 
In $2.5 \ldots 3$ hours of structure formation process at ambient temperature of $23 \ldots 25^{\circ} \mathrm{C}$ the candy body has a solid crystalline structure with the strength $4.103 \mathrm{~g}$ (Fig. 7).

The study on adhesive properties of the candy mass helps to evaluate the possibility of using various molding techniques for the manufacture of candy bodies.

The violation of production modes, moisture migration between the layers and syneresis during the storage leads to weakening of the adhesive interactions and changing in structural and mechanical characteristics of the products.

While forming the adhesive bonding through the combination of jelly and whipped semi-finished products in the combined body, highly viscous masses come into contact. In this case, for describing the process of contact formation rheological characteristics of the adhesive and the terms of the contact become important depending on the method of molding semi- finished products.

The molding of combined jelly-whipped candies can be produced with methods of co-extrusion, smearing followed by cutting, and casting.

The practice of molding by co-extrusion method showed that for each production it is necessary to make corrections of technological modes taking into account the constructive features of the molding equipment, or using them for combining confectionery masses close by rheological characteristics and having thixotropic properties [13].

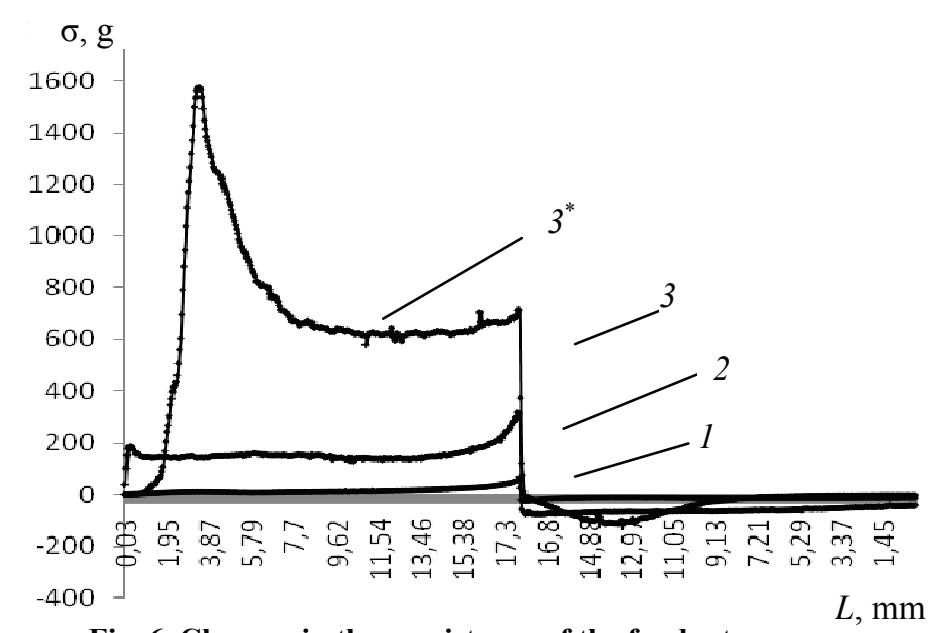

Fig. 6. Changes in the consistency of the fondant mass in the process of structuring after casting in: $1-15 \mathrm{~min} ; 2-35 \mathrm{~min} ; 3-60 \mathrm{~min}$

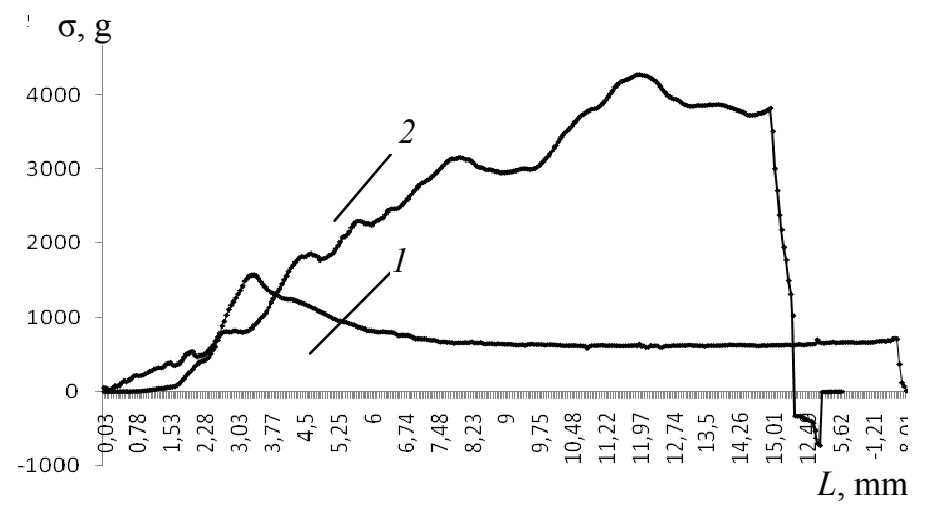

Fig. 7. Changes in the consistency of fondant mass in the process of structuring in, min: $1-15 ; 2-60$ 
The formation of candies by casting and smearing minimizes mechanical effect on the formable candy mass which does not destroy their structure and reduces the residual stress at the phase boundary. The smearing method allows making multilayer products, but in the process of cutting there may be possible violations of structures, displacement of the layers due to their deformation (Fig. 8).

The formation of jelly-whipped candies was performed by the smearing method followed by cutting and casting. The ability to control rheological properties of the jelly mass by changing the temperature at the molding stage is a determining factor in the choice of jelly layer as the top. When the temperature is increased, the viscosity of the jelly mass decreases non-linearly with average increase of temperature by $1{ }^{\circ} \mathrm{C}$ per $0.01 \mathrm{~Pa} \cdot \mathrm{s}$ [4]. At low viscosity the liquid adhesive wets the surface of the substrate providing a flawless full contact with the whipped mass with the maximum filling of micropores on the surface, but there is a formation of adhesive interaction and hardening of adhesive contact. However, even in this case, the adhesive strength of the contact is insufficient to prevent full separation of the structure by mechanical action on the semi-finished product during cutting the layer obtained by smearing or

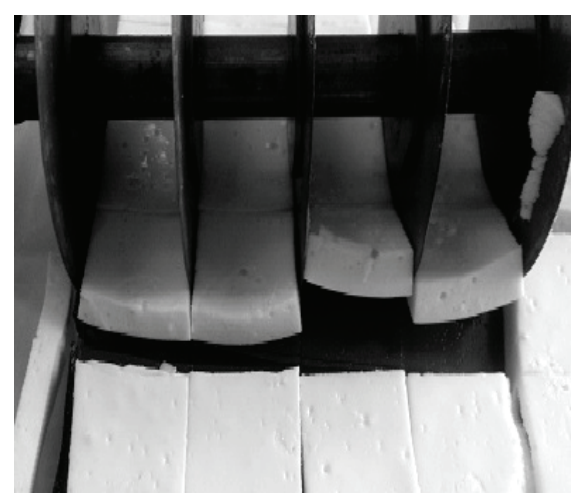

Fig. 8. Adhesion failure in forming combined bodies by smearing and cutting methods

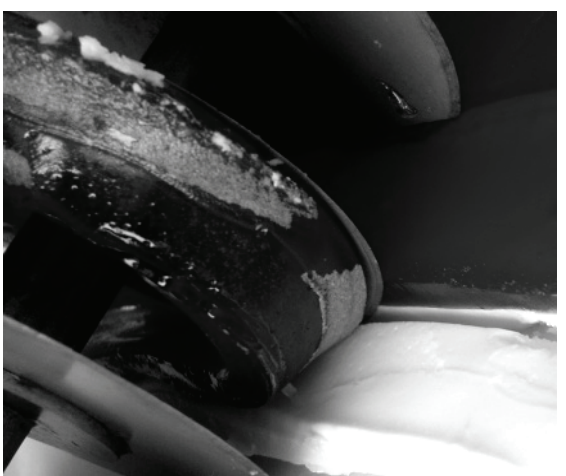

Fig. 9. Mixed destruction of adhesive compound in forming combined candy bodies by smearing and cutting methods during removing candy bodies made by the method of casting to the starch forms (Fig. 9).

When adding vegetable powders in the whipped layer in the amount of less than $2 \%$, the adhesive strength between the layers of the body does not differ significantly from indicators obtained for the combined bodies without additives. Introducing powders into the whipped layer in the amount more than $10 \mathrm{wt}$. \% leads to excessive development of microrelief which adversely affects the achievement of maximum contact area: a large number of connections reduces the mobility of macromolecules in the boundary layer, increases internal pressure, changes the structure of the surface layer, which results in defective areas that serve as centers where the destruction of adhesive compounds begins [7,14]. The maximum adhesion between the layers of candy mass is attained by adding vegetable powders in the whipped layer in the amount of 5-10 wt. $\%$, in the jelly layer - less than $3 \%$, while the strength of adhesion contacts increases by more than $30 \%$ compared to control samples (Fig. 10, 11).

Based on the above, it can be concluded that adding the carrot powder into the whipped mass allows to improve the contact area of the adhesive-substrate and to increase the adhesive connection strength due to the formation of a rough surface of the whipped mass and maximum filling of microdefects in the jelly mass. Moreover, the persistence of structural and mechanical properties of the whipped mass in the result of enhancing foam frame by rough fibers of the carrot powder provides the structuring capacity of the whipped layer and allows the operation of casting the jelly mass with 


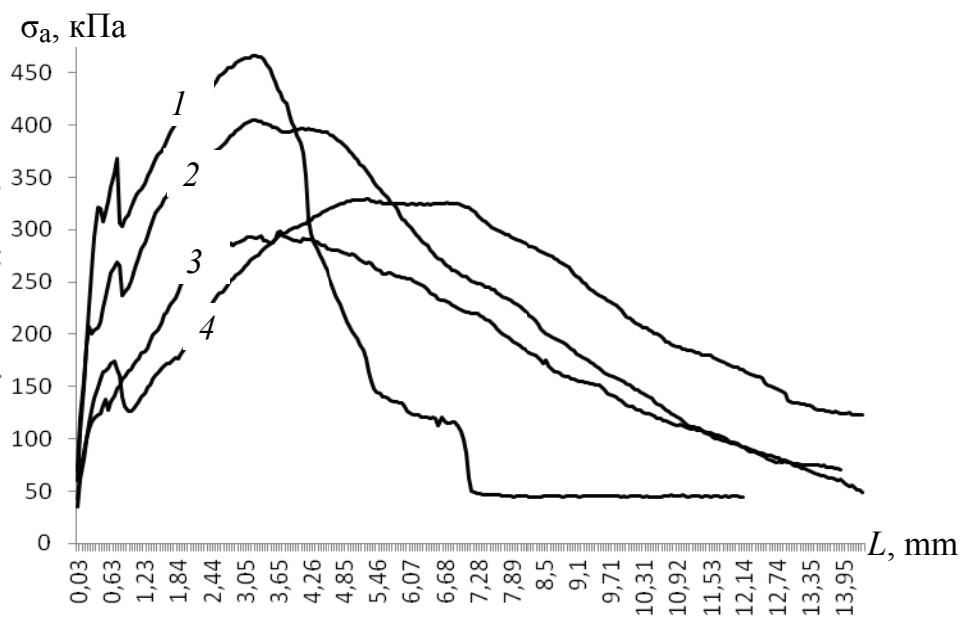

Fig. 10. Dependence of adhesive contacts strength on the depth of separation with the powder in the whipped mass and molding temperature of the jelly layer: $1-5 \%, 105{ }^{\circ} \mathrm{C} ; 2-5 \%, 95{ }^{\circ} \mathrm{C} ; 3$ - without powders, $95{ }^{\circ} \mathrm{C} ; 4$ - without powders, $105^{\circ} \mathrm{C}$

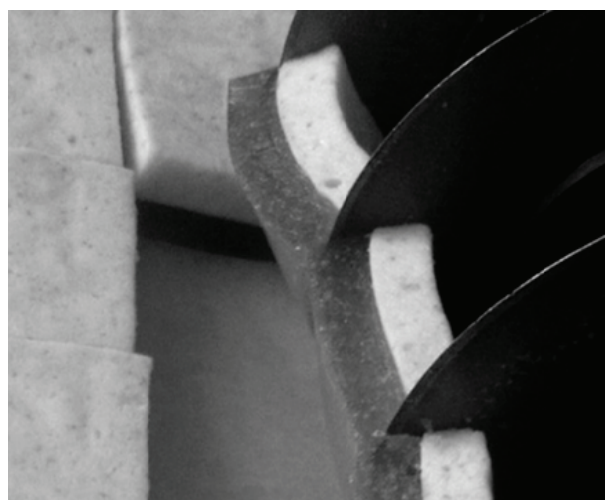

Fig. 11. Cutting of combined candy bodies with $5 \%$ carrot powder in the whipped layer; $3 \%$ powder pumpkin in the jelly layer

density of $1350 \mathrm{~kg} \cdot \mathrm{m}^{3}$ at $45 \ldots 60$ minutes after the formation. Vegetable powders having high water-binding capacity absorb moisture from the candy mass surface to improve their adhesion to the combinable layer. Adding powders into the jelly mass reduces jelly strength and allows to change the adhesive tense on its surface which has a positive impact on the quality of the adhesive contact with the whipped mass [14]. The studies have shown that during tests of control samples there is usually a mixed adhesive breaking, and that during tests of samples with the addition of vegetable powders the breaking is predominantly cohesive.

\section{Technological aspects of using the results of rheological studies}

According to the results of studies on rheological properties, temperature modes for specific stages of candy production were set (Table 1).

Based on the influence of phytonutrients dependencies on structural and mechanical characteristics of the fondant and whipped masses, the recommendations were made for the conditions and methods of molding (Table 2). 
Temperature modes for specific stages of candy production

\begin{tabular}{l|c|c|c}
\hline \multirow{2}{*}{ Candy mass } & \multicolumn{3}{|c}{ Production stages, ${ }^{\circ} \mathrm{C}$} \\
\cline { 2 - 4 } & whipping & tempering & forming \\
\hline \multirow{2}{*}{ Fondant } & $65 \ldots 75$ & \multicolumn{3}{|c}{ Control } \\
Jelly & - & $70 \ldots 75$ & $65 \ldots 70$ \\
Whipped & $55 \ldots 65$ & $85 \ldots 95$ & $75 \ldots 90$ \\
\hline \multicolumn{3}{|c|}{ New recipe } & $45 \ldots 55$ \\
Fondant & $75 \ldots 85$ & $85 \ldots 95$ & $80 \ldots 85$ \\
Jelly with the extract & - & $80 \ldots 85$ & $75 \ldots 80$ \\
\multicolumn{1}{|c|}{ powder } & - & $85 \ldots 95$ & $95 \ldots 105$ \\
Whipped & $65 \ldots 70$ & - & $65 \ldots 70$ \\
\hline
\end{tabular}

Table 2

Recommended methods of molding candy mass at different temperatures

\begin{tabular}{|c|c|c|}
\hline \multirow{2}{*}{ Molding temperature, ${ }^{\circ} \mathrm{C}$} & \multicolumn{2}{|c|}{ Candy mass } \\
\hline & control & new recipe \\
\hline Fondant mass $>70$ & \multicolumn{2}{|c|}{ Casting followed by prolonged structure formation process } \\
\hline $40 \ldots 70$ & Casting, smearing & Smearing, pressing \\
\hline$<25 \ldots 40$ & \multicolumn{2}{|c|}{ Not recommended } \\
\hline Whipped mass $>60$ & \multicolumn{2}{|c|}{ Casting } \\
\hline $45 \ldots 60$ & Casting, smearing & Smearing \\
\hline $30 \ldots 45$ & Smearing & Smearing, pressing \\
\hline $25 \ldots 30$ & Smearing & Settling, pressing \\
\hline$<25$ & \multicolumn{2}{|c|}{ Not recommended } \\
\hline
\end{tabular}

When the molding temperature is above $70{ }^{\circ} \mathrm{C}$, the fondant structuring occurs after casting the bodies, thus the shear rate in the molding can be set arbitrarily. Temporizing of the bodies proceeds to a temperature of $20 \ldots 22^{\circ} \mathrm{C}$ for $35 \ldots 40$ minutes. Structuring process is characterized by the formation of crystallization centers with the addition of new molecules to the grid and proceeds spontaneously as it is accompanied by decreasing free energy of the system. When using the fondant mass as fillings at the temperature range of $40 \ldots 70{ }^{\circ} \mathrm{C}$, their supply to product bodies may be performed at any shear rate. While molding the fondant mass at temperatures below $40^{\circ} \mathrm{C}$ in order to avoid destroying the structure of the mass, the shear rate should be less than the lowest critical rate, i.e. $25 \mathrm{~s}^{-1}$.

Structuring occurs after casting of the whipped mass at high temperatures, so the shear rate during the formation process can be set arbitrarily. At temperatures below $60{ }^{\circ} \mathrm{C}$ the process of jelly formation begins, therefore the impact on the structure should be minimal. This requirement corresponds to the smearing method. For the temperature range of $30 \ldots 45^{\circ} \mathrm{C}$ the whipped mass made according to traditional recipes should be formed by smearing, while for the whipped mass with the addition of vegetable powders the pressing method can be used because the moulded products retain their shape well in the form of a slice. If the temperature is $25 \ldots 30^{\circ} \mathrm{C}$ the whipped mass with the addition of vegetable powders can be molded by settling. Thus molded product 
retains their shape well as the process of structure formation by the time of molding has largely been completed. To prevent the destruction of the mass structure during the molding the shear rate should be below the lowest critical rate, i.e. $30 \mathrm{~s}^{-1}$.

\section{Conclusions}

The studies proved operating parameters at different stages of candy production from semi-finished products with different rheological properties. It is found that the nature of rheological curves in the studied range of shear rates is similar to candy mass with the addition of powders made from drug-technical and vegetable raw materials with similar values of dispersion indicators, water retention and adsorption capacity. The resulting patterns allow extending the application area of the research results for confectionery masses of different composition provided a preliminary analysis of physico-chemical properties of introduced additives. The practical use of recommendations contained in the article can be useful for firms producing confectionery products while expanding the range of products with the use of powders and extracts from plant raw materials.

\section{References}

1. Chetana R., Sripathi K., SunkiReddy Y. Reddy European Food Research and Technology, 2004, Vol. 218, no. 4. pp. 345-348.

2. Matveenko C.N., Kirsanov E.A. Vestnik Moskovskogo Universiteta (Bulletin of Moscow University), 2011, Vol. 52, no. 4.

3. Belokrylov Y.F., Kalinin S.M., Lamkin A.M., Machikhin Y.A. Konditerskoe proizvodstvo, 2005, no. 4, pp. 43-44.

4. Leonov D.V., Muratowa E.I., Dvoretsky S.I. Voprosy sovremennoi nauki $i$ praktiki. Universitet im. V.I. Vernadskogo, 2011, no. 3, pp. 378-383.

5. Magomedov G.O., Arsanukaev I.H., Zhuravlev A.A. Khranenie i pererabotka sel'khozsyr'ya, 2009, no. 12, pp. 35-38.

6. Carolina P.K., Schumacher A.B., Lígia D.F. Marczak, Tessaro I.C., Nilo S.M. Cardozo. Food Hydrocolloids, 2011, vol. 25, no. 3, pp. 299-306.

7. Zimon A.D., Yevtushenko A.M. Adgeziya pishchevykh mass (Adhesion of food masses), Moscow: DeLi print, 2008, 398 p.

8. Muratowa E.I., Smolikhina P.M. Reologiya konditerskikh mass: monografiya (Rheology of confectionery masses: the monograph), Tambov: TSTU publisher house, 2013, 188 p.

9. Muratowa E.I., Smolikhina P.M. Proceeding of international scientific and technical Conference named after Leonardo da Vinci. № 1, Berlin, 2013, pp. 177-185.

10. Zubchenko A.V. Fiziko-khimicheskie osnovy tekhnologii konditerskikh izdelii: uchebnik (Technology for confectionery production), Voronezh: Publisher Voronezh State Technological Academy, 2001, 389 p.

11. Gorbatov, A. Structural-mechanical characteristics of food products [Text] / A.V. Gorbatov, A. M. Maslov, Y.A. Machikhin and others; Ed. by A.V. Gorbatov. - M: Light and food industry here, 1982. - $296 \mathrm{p}$.

12. Zubchenko A.V. Vliyanie fiziko-khimicheskikh protsessov na kachestvo konditerskikh izdelii (The Influence of physico-chemical processes on the quality of confectionery products), Moscow: Agropromizdat, 1986, 296 p.

13. Obolkina V.I., Lebedeva L.N., Zalevskaya N.O. Produkty \& Ingredienty, 2008, no. 8 (50), p. 36-37.

14. Muratova E.I., Smolikhina P.M. Vestnik Voronezhskogo gosudarstvennogo universiteta inzhenernykh tekhnologii, 2012, no. 3, pp. 82-86. 


\title{
Реологические свойства конфетных масс: результаты исследований и практические приложения
}

\author{
Е. И. Муратова, П. М. Смолихина
}

\section{Кафедра «Технологии и оборудование пищевых и химических производств», ФГБОУ ВПО «ТГТУ»; topt@topt.tstu.ru}

Ключевые слова: реология, адгезия, конфетные массы, технологические режимы, порошки из растительного сырья.

Аннотация: Проведен анализ отечественных и зарубежных информационных источников, посвященных изучению реологического поведения кондитерских масс, и доказана необходимость комплексного изучения реологических свойств сырья, полуфабрикатов и готовой продукции для обоснования оптимальных режимов производства и получения изделий с заданными структурномеханическими характеристиками.

Представлены результаты исследований реологического поведения желейных, помадных и сбивных конфетных масс различного состава, изготовленных по классическим рецептурам и с внесением порошков и водно-спиртовых экстрактов из растительного сырья.

Установлен характер изменения пластической прочности полуфабрикатов в зависимости от режимов выстойки и влияния добавок растительного происхождения на процесс структурообразования. Изучено влияние фитодобавок и овощных порошков на прочность адгезионных контактов между слоями конфетных масс при формовании многослойных кондитерских изделий.

На основе учета особенностей физико-химических взаимодействий добавок растительного происхождения с другими рецептурными ингредиентами конфетных масс представлено объяснение механизмов их влияния на реологические свойства полуфабрикатов и структурно-механические характеристики готовых изделий.

На основании результатов исследований влияния дозировки и дисперсности фитодобавок и овощных порошков на вязкость конфетных масс при различных температурах и скоростях деформации разработаны рекомендации для выбора режимов термомеханической обработки помадной и желейной масс при темперировании и отливке.

\section{Список литературы}

1. Chetana, R. Rheological Behavior of Syrups Containing Sugar Substitutes / R. Chetana, K. Sripathi, SunkiReddy Y. Reddy // European Food Research and Technology. - 2004. - Vol. 218, No. 4. - P. $345-348$.

2. Матвеенко, В. Н. Вязкость и структура дисперсных систем / В. Н. Матвеенко, Е. А. Кирсанов // Вест. Моск. ун-та. - 2011. - Т. 52, № 4. C. $243-276$.

3. Вискозиметрия сбивных конфетных масс / Ю. Ф. Белокрылов [и др.] // Кондитерское производство. - 2005. - № 4. - С. 43 - 44.

4. Леонов, Д. В. Моделирование и оптимизация реологических свойств желейных полуфабрикатов / Д. В. Леонов, Е. И. Муратова, С. И. Дворецкий // Вопр. соврем. науки и практики. Ун-т им. В. И. Вернадского. - 2011. - № 3(34). C. $378-383$. 
5. Моделирование и оптимизация структурно-механических свойств мармелада / Г. О. Магомедов [и др.] // Хранение и переработка сельхозсырья. 2009. - № 12. - C. 35 - 38 .

6. Rheological Behavior of Blueberry (Vaccinium Ashei) Purees Containing Xanthan Gum and Fructose as Ingredients / P. K. Carolina [at al.] // Food Hydrocolloids. - 2011. - Vol. 25, No. 3. - P. 299 - 306.

7. Зимон, А. Д. Адгезия пищевых масс / А. Д. Зимон, А. М. Евтушенко. М. : ДеЛи принт, 2008. - 398 с.

8. Муратова, Е.И. Реология кондитерских масс: монография / Е. И. Муратова, П. М. Смолихина. - Тамбов : Изд-во Тамб. гос. техн. ун-та, 2013. $-188 \mathrm{c}$.

9. Muratowa, E. I. The Use of Regional Raw Materials for Creating Confectionery Products for Functional Purposes / E. I. Muratowa, P. M. Smolikhina // Proceeding of International Scientific and Technical Conference after Leonardo da Vinci. - Berlin, 2013. - No 1. - P. 177 - 185.

10. Зубченко, А. В. Физико-химические основы технологии кондитерских изделий : учебник / А. В. Зубченко. - Воронеж : Изд-во Воронеж. гос. технол. акад., 2001. -389 с.

11. Горбатов, А. В. Структурно-механические характеристики пищевых продуктов / А. В. Горбатов, А. М. Маслов, Ю. А. Мачихин. - М. : Легкая и пищевая промышленность, 1982. - 296 с.

12. Зубченко, А. В. Влияние физико-химических процессов на качество кондитерских изделий / А. В. Зубченко. - М. : Агропромиздат, 1986. - 296 с.

13. Оболкина, В. И. Формование комбинированных кондитерских изделий / В. И. Оболкина, Л. Н. Лебедева, Н. О. Залевская // Продукты \& Ингредиенты. 2008. - № 8 (50). - С. 36 - 37 .

14. Смолихина, П. М. Изучение адгезионных свойств конфетных масс для обоснования способов формования конфет с комбинированными корпусами / П. М. Смолихина, Е. И. Муратова // Вест. Воронеж. гос. ун-та инженер. технологий. - 2012. - № 3. С. 82 - 85.

\section{Reologische Eigenschaften der süßlichen Massen: Ergebnisse der Forschungen und die praktischen Anlagen}

Zusammenfassung: Es ist die Analyse der einheimischen und ausländischen informativen Quellen, die dem Studium des reologischen Verhalten der Konditormassen gewidmet sind, durchgeführt. Es ist die Notwendigkeit des komplexen Studiums der reologischen Eigenschaften des Rohstoffs, der Halbfabrikate und der Fertigware für die Begründung der optimalen Regimes der Produktion und des Erhaltens der Erzeugnisse mit den aufgegebenen strukturellmechanischen Charakteristiken rechtfertigt.

Es ist der Charakter der Veränderung der plastischen Haltbarkeit der Halbfabrikate je nach den Regimes der Ablagerung des Halbfabrikates und des Einflusses der Zusätze der Pflanzenherkunft auf den Prozess der Strukturbildung bestimmt.

Aufgrund der Ergebnisse der Forschungen des Einflusses der Dosierung und der Dispersität der Phytozusätze und der Gemüsepulver auf die Zähigkeit der süßlichen Massen bei verschiedenen Temperaturen und den Geschwindigkeiten der Deformation sind die Empfehlungen für die Auswahl der Regimes der thermomechanischen Bearbeitung der Crème- und Geleemassen bei dem Temperieren und dem Guß entwickelt. 


\section{Propiétés rhéologiques des masses de la pâtisserie: résultats de la recherche et applications pratiques}

Résumé: Est effectuée une analyse des sources d'information nationaux et étrangers consacrés à l'étude du comportement rhéologique des masses de la pâtisserie. Sont présentés les résultats de la recherche rhéologique du comportement des masses de la pâtisserie de différente composition de recettes. Est constaté le caractère du changement de la résistance plastique en fonction des régimes de la production. Sont étudiés les effets des additions et des poudres de légumes sur la résistance des contacts entre les couches d'adhérence des masses de la pâtisserie.A la base des caractéristiques physico-chimiques des interactions d'additives d'origine végétale avec d'autres ingrédients des masses est présentée l'explication des mécanismes de leur influence sur les propriétés rhéologiques des produits semi-finis ainsi que les caractéristiques structurelles et mécaniques. Sont élaborées des recommandations pour le choix des régimes du traitement thermomécanique des masses de la pâtisserie.

Авторы: Муратова Евгения Ивановна - кандидат педагогических наук, доцент кафедры «Технологии и оборудование пищевых и химических производств»; Смолихина Полина Михайловна - ассистент кафедры «Технологии и оборудование пищевых и химических производств», ФГБОУ ВПО «ТГТУ».

Рецензент: Гатапова Наталья Цибиковна - доктор технических наук, профессор, заведующая кафедрой «Технологические процессы, аппараты и техносферная безопасность», ФГБОУ ВПО «ТГТУ». 